Article

\title{
Investigating the Dynamic Interlinkages between Exchange Rates and the NSE NIFTY Index
}

\author{
Vijay Victor ${ }^{1}\left(\mathbb{D}\right.$, Dibin $K_{K}{ }^{2, * \mathbb{D}}$, Meenu Bhaskar ${ }^{3}$ and Farheen $\mathrm{Naz}^{4}$ \\ 1 Department of Economics, CHRIST (Deemed to Be University), Bangalore 560029, India; \\ vijay.victor@christuniversity.in \\ 2 Department of MBA, SCMS, Cochin 683106, India \\ 3 Doctoral School of Management, Indian Institute of Management (IIM), Kozhikode 673570, India; \\ meenub14phd@iimk.ac.in \\ 4 Doctoral School of Management and Business Administration Sciences, Szent Istvan University, \\ 2100 Godollo, Hungary; Farheen.Naz@phd.uni-szie.hu \\ * Correspondence: dibin@scmsgroup.org; Tel.: +91-9769470827
}

Citation: Victor, Vijay, Dibin K K, Meenu Bhaskar, and Farheen Naz. 2021. Investigating the Dynamic Interlinkages between Exchange Rates and the NSE NIFTY Index. Journal of Risk and Financial Management 14: 20. https://doi.org/ 10.3390/jrfm14010020

Received: 9 November 2020 Accepted: 30 December 2020 Published: 5 January 2021

Publisher's Note: MDPI stays neutral with regard to jurisdictional clai$\mathrm{ms}$ in published maps and institutional affiliations.

Copyright: (C) 2021 by the authors. Licensee MDPI, Basel, Switzerland. This article is an open access article distributed under the terms and conditions of the Creative Commons Attribution (CC BY) license (https:// creativecommons.org/licenses/by/ $4.0 /)$.

\begin{abstract}
This study aims at examining the short-run and long-run dynamic linkages among exchange rates and stock market index in India through a structured cointegration and Granger causality tests. Daily exchange rates of USD, EUR, CNY, JPY, and GBP to INR along with the daily movement of NSE NIFTY for a period spanning 13 years from 6 September 2005 to 31 December 2018 were used for the analysis. The results reveal that there is no evidence for a stable long-run relationship between NSE NIFTY and the exchange rates under study. However, the VAR-based Granger causality test shows that USD, JPY, and CNY have short-run causal relationship with NSE NIFTY. The NSE NIFTY also seemed to have an influence on USD expressed in terms of Indian rupee. The impulse response analysis further supports the results of the Granger causality test and provides information on the time required for the NSE NIFTY index to recover from a shock caused by the fluctuation in exchange rates.
\end{abstract}

Keywords: NIFTY; currencies; Granger causality; impulse response

\section{Introduction}

Fluctuation in exchange rates is one of the significant factors that affect stock prices, which subsequently influences a firm's market value. Despite the fact that this topic has been discussed worldwide, there is still a lack of unanimity in the literature regarding the relationship between exchange rates and stock market indices (Mroua and Trabelsi 2020). As financial theory describes, the interest rates and exchange rates significantly influence the value of a firm and the upward and downward movements of the exchange rate play a pivotal role in determining the stock prices. In both developed as well as developing countries, the stock market plays a crucial role as far as financial intermediation is concerned. It channels the funds in an economy from surplus units to deficit units through resource mobilization, which is critical in the process of expansion and growth of an economy. Hence, the stock market acts as a channel in mobilizing savings and helps in the efficient allocation of funds, thereby fostering economic growth (Olugbenga 2012; Alile 1984).

Various hypotheses support the causal relationship between exchange rates and stock prices, such as, goods market approach, which defines that the competitive nature of the firm is affected by the change in exchange rates. It signifies that the exchange rate fluctuations affect the earning value and cost of funds along with their stock prices because companies start to borrow in foreign currencies in order to fund their processes (Dornbusch and Fischer 1980). The export of goods becomes attractive when there is a depreciation in the local currency, and it leads to an increase in foreign demand. As a result, the revenue of 
a firm appreciates along with the appreciation in the firm's value and stock prices. Similarly, when the local currency appreciates, it leads to a decrease in profits of a firm that exports goods as there is a decrease in its products' foreign demand. However, there is a change in the sensitivity of the value of the firm to the change in the exchange rate, and it depends on whether it is an importing firm or an exporting firm (Nath and Samanta 2003).

An alternative approach is provided by the portfolio balance models, which stressed the role of transactions in capital account in studying the relationship between stock prices and exchange rates. For example, capital inflows from foreign investors have been drawn by an attractive performance of a stock market, which increases the demand for domestic currency. On the other hand, the demand for the local currency depreciates when there is a fall in stock prices as the foreign investors start selling their stocks (Adebiyi et al. 2009). Moreover, with time, foreign investment can increase in local equities as a result of the profits of international broadening to foreign investors. Hence, the upward and downward movements of stock prices affect the money demand and exchange rates because the liquidity demand and wealth of investors could be a factor that affects the stock market performance (Mishra 2004).

Several theories have suggested a causal relationship between the exchange rates and stock prices. Nevertheless, evidence that provides mixed results is also widely available. For instance, out of 171 multinational firms of Japan, only 25 Percent have shown a significant disclosure of exchange rate over the stock market (He and $\mathrm{Ng}$ 1998). Another study showed the empirical results that there was only a negligible impact of weekly exchange rate movement on the value of industry indices in many countries (Griffin and Stulz 2001). Moreover, some theories failed to identify a significant relationship between the movement of dollar prices and stock returns of US firms, for instance, Jorion (1990); Bartov and Bodnar (1994), etc.

Considering the interrelationship between the stock market indices and exchange rates, it is imperative that more studies need to be conducted in this regard. However, there is still a dearth of comprehensive studies that investigate this dynamic interrelation in the Indian context. The main aim of this study is to examine the linkages between the exchange rates and NSE NIFTY index using the daily data of NSE NIFTY closing values and exchange rates spanning 13 years (2005-2018). The objective is to identify whether variations in exchange rates influence the NSE NIFTY closing values, which can be a significant cue for the investors while making investment decisions. The NIFTY 50 is an index that indicates the weighted average of fifty Indian companies that are listed on the National Stock Exchange of India (NSE), which is the largest stock market in the country. This study analyses the long-run relationship between the exchange rate of US Dollar (USD), Euro (EUR), Chinese Yuan (CNY), Japanese Yen (JPY), British Pound (GBP) to Indian Rupee (INR) with NSE NIFTY index using a Johansen cointegration test. The short-run relationship between the above-mentioned variables is examined using a VAR Granger Causality test and impulse response function.

\section{Literature Review}

In a study conducted by Ibrahim (2000), the interactions between stock prices and exchange rates in Malaysia were examined using a Cointegration and Granger causality test. The study found no long-run relationship between stock prices and exchange rates, but evidence for cointegration was observed when M2 money supply and reserves were included in the analysis. The study construed that the short-run exchange rates did impact the stock market price. Likewise, other studies also supported that there is no significant relationship between the exchange rate and stock market indices in the long-run (Franck and Young 1972; Bhattacharya and Mukherjee 2002).

Phylaktis and Ravazzolo (2005) analyzed the short-run and long-run effects between stock prices and exchange rates and the channels through which exogenous shocks impact the markets of some Pacific Basin countries for a period between 1980 and 1998. A structured cointegration and multivariate Granger causality test were used for the analysis and 
the results showed a positive long-run and short-run causality between stock prices and exchange rates. Another study by Gulati and Kakhani (2012) to find a causal relationship between INR/Dollar exchange rates and stock market indices (SENSEX and NIFTY) for a period of 2004-2012 used Granger causality and correlation analysis. Their results showed that there is a weak positive correlation between stock price indices and exchange rates for the aforementioned period.

The nature of the causal relationship between exchange rates and stock market performances of Switzerland and Poland from 2001 to 2008 was examined using both linear and non-linear causality tests. The results showed that the performance of the stock market is a causal factor for changes in exchange rates (Portfolio approach) for Switzerland. For Poland, both portfolio and traditional approach where changes in exchange rates caused fluctuations in stock market prices had an impact on the exchange rates (Gurgul and Lach 2012).

A study conducted in Nigeria for the period between 2001 and 2011 shows no significant relationship between exchange rate and stock market prices. The result of the Granger causality test indicates the absence of causality between the All Share Index (ASI) and exchange rates, which show the independence of exchange rates and stock market index in Nigeria (Zubair 2013). Similarly, a study conducted by Lee and Zhao (2014) explained the short-run and long-run causal relationship between stock market prices and exchange rates in China for a period between 2002 and 2012 using cointegration tests, vector error correction (VEC) estimates, block exogeneity Wald tests, impulse responses, variance decomposition techniques, and structural break tests. The results showed a long-run causality from exchange rates to stock prices in Chinese stock markets and a short-run causality from Japanese yen and Korean won exchange rates to stock prices in Shanghai Stock Exchange strongly prevails, whereas in the Shenzhen Stock Exchange the causality is weak. The impact of the global financial crisis from 2007 to 2009 on the Chinese stock markets was found to be insignificant.

Chkili and Nguyen (2014) studied the upward and downward movement of exchange rates and stock market returns in a regime-switching environment for BRICS countries for 16 years (1997-2013) using Markov autoregressive model and VAR model. The results showed that the returns from the stock market were higher than exchange returns in all BRICS countries. Among BRICS countries, South Africa is less volatile, and Russia is more volatile and changes in exchange rate do not affect the stock market return of BRICS countries. Inversely, the impact from stock market returns to exchange rates is significant for all BRICS countries. Likewise, a study conducted for Karachi stock exchange (KSE 100 Index, Pakistan) using the Johansen cointegration test and Granger causality test showed that there was no long-run relationship between exchange rates and the stock market prices (Ihsan et al. 2015). Poornima and Ganeshwari (2016), in their study about stock exchange in India, found that there exists a unidirectional relationship between exchange rates and the NIFTY Index.

Another study about the Indian stock market and foreign exchange rates of USD, Euro, Yen, and Pound sterling against the Indian rupee (INR) was conducted for a period of five years, 2011-2015. The study used the Granger causality test to find the cause and effect relationship between the stock market index and the exchange rates. The study explains that the cause and effect between stock market indices (Sensex and NIFTY) shows an inverse relationship between returns from foreign exchange rates USD, GBP, EURO, and YEN and the relationship between currency returns to other currency returns against INR shows a positive relationship. This explains that the cause and effect relationship is unidirectional (Kumarasamy and Chellasamy 2017).

From the literature, it could be seen that most of the studies in the related area used cointegration and Granger causality to test the long-run and short-run relationship between exchange rates and stock market indices. This study using similar methods hypothesizes that: 
Hypothesis 1. There is a cointegrating relationship between the exchange rates and the NSE NIFTY index.

Hypothesis 2. USD Granger causes NSE NIFTY index.

Hypothesis 3. EUR Granger causes NSE NIFTY index.

Hypothesis 4. CNY Granger causes NSE NIFTY index.

Hypothesis 5. JPY Granger causes NSE NIFTY index.

Hypothesis 6. GBP Granger causes NSE NIFTY index.

\section{Methodology}

\subsection{Data Description}

The data used for the study were collected from the Bloomberg Terminal and National Stock Exchange (NSE) website. Daily exchange rates of USD, EUR, CNY, JPY, and GBP to INR along with the daily movement of NSE NIFTY 50 for a period spanning 13 years from 6 September 2005 to 31 December 2018 comprising 3286 observations were used for the analysis.

\subsection{Cointegration}

Regression analysis using non-stationary time series often makes the results spurious. Taking the first difference may not make the variables suitable for regression in most cases as information regarding co-movement may be lost in the process and ultimately result in poor forecasting (Sims 1980). In order to solve this issue, Engle and Granger (1987) suggested testing for cointegration among non-stationary time series. If the variables are cointegrated of the same order, then an "error correction" is said to exist, which explains the short-run dynamics between the cointegrated variables. In such cases, the appropriate method is to estimate the Vector Error Correction Model (VECM), which is the same as the Vector Auto Regression (VAR) in the first difference with a vector of cointegrating residuals. If the variables are not cointegrated, then a VAR model can be fitted.

\subsection{Granger Causality Test}

A time series $Y_{t}$ Granger causes another time series $X_{t}$, if the present values of $X$ can be predicted using the past values of $Y$ and other relevant information, which includes the past values of $X$ as well (Granger 1969). An F statistic is commonly used to interpret the results of causality. In the case of using more than two variables, such as an additional variable $Z$, which also mutually causes $X$ or $Y$, a multivariate framework could be used. The Granger causality test used in this study is carried out in a VAR framework, which provides a flexible environment to conduct the analysis. The methods followed in this study are based on the procedure given by Granger (1969) and Engle and Granger (1987). Nevertheless, the specific technique to be used mainly depended upon the presence of cointegration among the variables.

\subsection{Impulse Response Function}

An impulse response function in very simple terms could be explained as a technique used to examine the path of a variable of interest in a VAR model after encountering a shock. The transmission of a shock could be tracked with the help of an impulse response function which facilitates the proper assessment of the behavior of a variable (Alloza 2017). Two methods are commonly used to depict the dynamic behavior of a VAR model and to identify the sources of variability: Impulse Response Function (IRF) and Variance Decomposition. The variance decomposition method suffers from limitations that may affect the characteristics of impulses. The generalized impulse response functions propounded by Pesaran and Shin (1998) offer better results as compared to the former. This study uses the 
generalized impulse response function to analyze the dynamic behavior of the variables.

\section{Results and Discussion}

\subsection{Descriptive Statistics}

The descriptive statistics, along with the normality test for all the variables under study, are given in Table 1.

Table 1. Descriptive Statistics and Normality Test.

\begin{tabular}{ccccccc}
\hline Descriptive Statistics & NSE & USD & EUR & CNY & JPY & GBP \\
\hline Mean & 6256.61 & 54.2226 & 68.5863 & 8.12960 & 0.53318 & 85.0561 \\
Std. Dev & 2298.33 & 9.79310 & 8.73385 & 1.84054 & 0.09875 & 9.36010 \\
Skewness & 0.46153 & 0.15552 & 0.07112 & -0.14761 & -0.51928 & 0.23232 \\
Kurtosis & 2.28362 & 1.54340 & 2.09774 & 1.45031 & 2.26508 & 2.19437 \\
Wilk-Shapiro & 0.91757 & 0.93570 & 0.97576 & 0.93865 & 0.95046 & 0.95835 \\
p-Value & 0.00000 & 0.00000 & 0.00000 & 0.00000 & 0.00000 & 0.00000 \\
\hline
\end{tabular}

Note: SW test null-Normal Distribution.

The descriptive statistics results include the mean values showing the average daily exchange rate variations, standard deviation indicating the extent of volatility from the mean value, skewness and kurtosis for normality tests are given in the table above. The Shapiro-Wilk normality test was also used to test the normality of the time series distributions. As can be seen, the kurtosis values are higher than the specified threshold, which implies that the time series data do not follow normal distribution. This is further confirmed using a Shapiro-Wilk Test, which rejects the null hypothesis that the data follow a normal distribution.

\subsection{Stationarity Test}

In order to test for cointegration, it is important to check the order of integration. The results of both Augmented Dickey Fuller (ADF) test and Kwiatkowski-Phillips-SchmidtShin (KPSS) test show that the variables are not stationary at level but are stationary after first differencing. Table 2 shows the results of the stationarity test.

Table 2. Tests for Stationarity.

\begin{tabular}{cccccc}
\hline \multirow{2}{*}{ Variable } & \multicolumn{2}{c}{ Levels } & \multicolumn{2}{c}{ First Difference $(\Delta \ln )$} & \multirow{2}{*}{ Inference } \\
\cline { 2 - 5 } & $\begin{array}{c}\text { Dickey } \\
\text { Fuller }\end{array}$ & KPSS & $\begin{array}{l}\text { Dickey } \\
\text { Fuller }\end{array}$ & KPSS & \\
\hline NSE & -2.6286 & $28.66^{* *}$ & $-14.14^{* *}$ & 0.063 & $\mathrm{I}(1)$ \\
USD & -2.7225 & $30.35^{* *}$ & $-13.78^{* *}$ & 0.085 & $\mathrm{I}(1)$ \\
EUR & -2.6925 & $23.73^{* *}$ & $-14.78^{* *}$ & 0.041 & $\mathrm{I}(1)$ \\
CNY & -1.8834 & $30.81^{* *}$ & $-13.64^{* *}$ & 0.156 & $\mathrm{I}(1)$ \\
JPY & -2.0957 & $20.89^{* *}$ & $-13.96^{* *}$ & 0.088 & $\mathrm{I}(1)$ \\
GBP & -2.0798 & $13.56^{* *}$ & $-14.59^{* *}$ & 0.065 & $\mathrm{I}(1)$ \\
\hline
\end{tabular}

Note: Significant at $0.05,{ }^{* *}$ Significant at 0.01 .

Line plots for the exchange rates and NSE NIFTY index for the period under study are shown in Figure 1. 


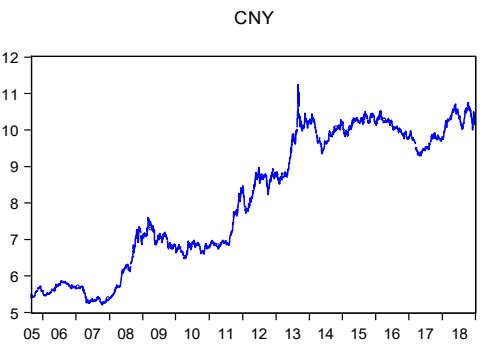

JPY

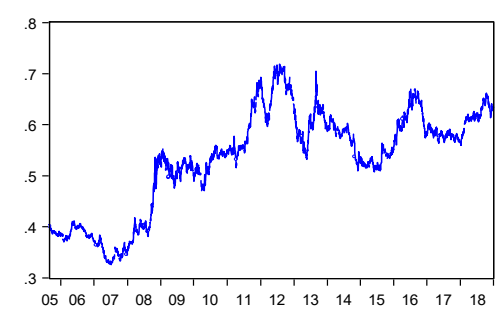

EUR

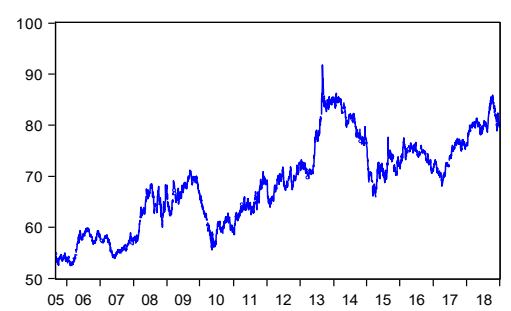

NIFTY

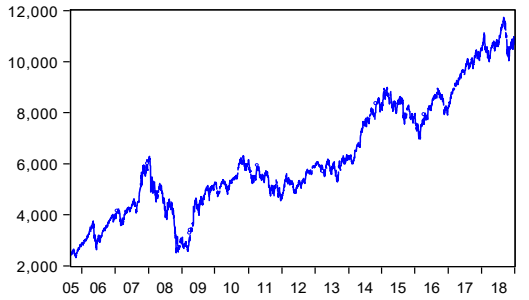

GBP

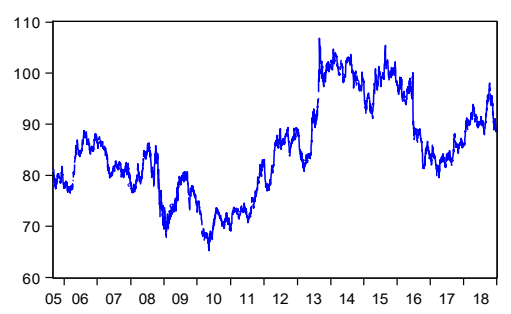

USD

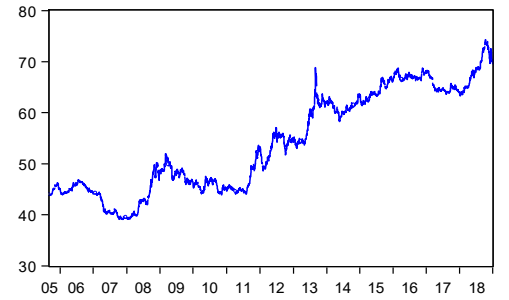

Figure 1. Line plots of the variables over the study period.

\subsection{Test for Cointegration}

Now that the variables follow the same level of integration, the existence of cointegration among them can be tested. If two variables $x$ and $y$ are $\mathrm{I}(1)$ processes and their linear combination et $=\beta 0+\beta 1 X+\beta 2 Y$, is stationary then the variables are said to be cointegrated of the order $(1,1)$. The stochastic trends of these variables linked, such that they cannot drift apart in the long-run, pointing to an equilibrium relationship between them.

A Johansen multivariate cointegration test (Johansen 1988) was carried out to identify a cointegrating relationship between the variables. The test statistic, critical values, and rank of cointegration are shown in Table 3.

Table 3. Johansen Cointegration-Trace Statistic with linear trend.

\begin{tabular}{ccccc}
\hline \multirow{2}{*}{ Rank } & Test Statistic & \multicolumn{3}{c}{ Critical Values } \\
\cline { 3 - 5 } & & $\mathbf{1 0} \mathbf{~ p c t}$ & $\mathbf{5}$ pct & $\mathbf{1}$ pct \\
\hline $\mathrm{r} \leq 5$ & 1.17 & 6.50 & 8.18 & 11.65 \\
$\mathrm{r} \leq 4$ & 5.50 & 15.66 & 17.95 & 23.52 \\
$\mathrm{r} \leq 3$ & 13.27 & 28.71 & 31.52 & 37.22 \\
$\mathrm{r} \leq 2$ & 22.52 & 45.23 & 48.28 & 55.43 \\
$\mathrm{r} \leq 1$ & 35.34 & 66.49 & 70.60 & 78.87 \\
$\mathrm{r} \leq 0$ & 64.41 & 85.18 & 90.39 & 104.20 \\
\hline
\end{tabular}

The test results reject the hypothesis that the variables are cointegrated as the test statistic value for $r \leq 0$ cannot be rejected at 10 pct, 5 pct, and 1 pct. The test statistic values are not higher than the critical values for other cointegrating ranks as well. The results imply that there exists no long-run relationship between the exchange rates and the NIFTY index. Hypothesis 1 is rejected as no evidence could be found for a cointegrating relationship between the variables. The finding that USD to INR does not have a long-run relationship with NSE NIFTY index is corroborated by Bhuvaneshwari and Ramya (2017) using Johansen Cointegration test.

\subsection{Causality Test}

After finding no evidence for long-run relationship between the variables, the shortrun causation effect was investigated using the Granger causality test. Stationarity of the variables is a prerequisite for the Granger causality test. Hence the log difference of the 
variables was used to ensure that the variables follow constant statistical properties over the period of analysis. A unidirectional causality test using Granger causality test in VAR environment was carried out to check whether the changes in the exchange rate can predict the NIFTY index. The graphical representation of the variables in their first log difference is shown in Figure 2.

D_LOG_NIFTY

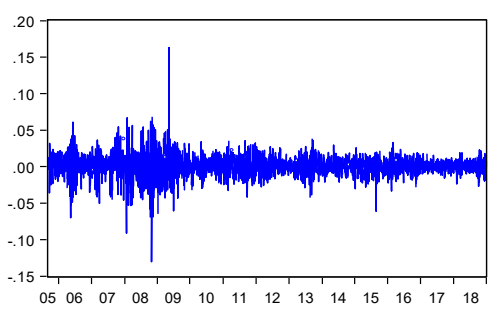

D_LOG_GBP

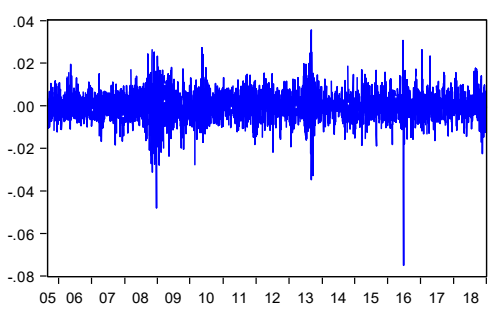

D_LOG_USD

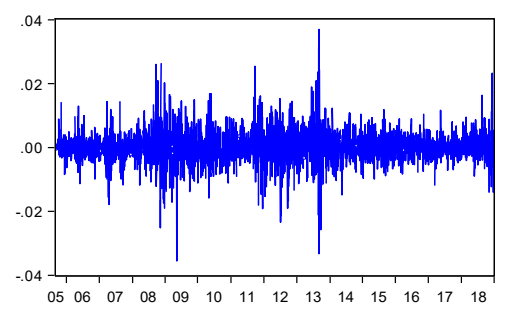

D_LOG_EUR

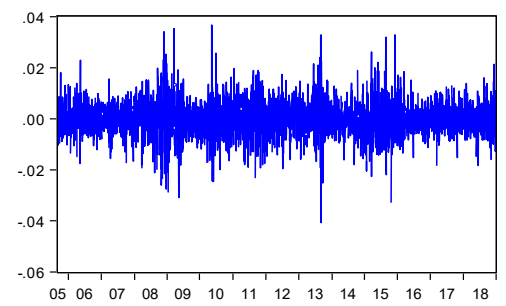

D_LOG_JPY

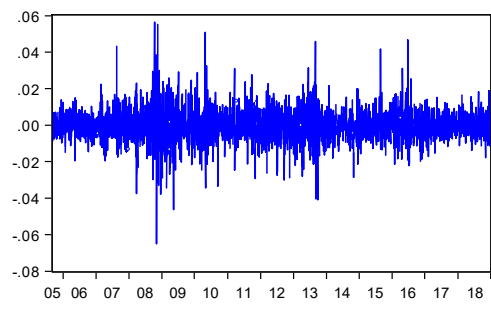

D_LOG_CNY

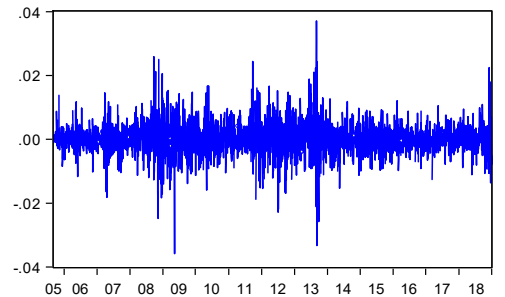

Figure 2. Variables after first log difference.

This study's scope is confined to the assessment of the impact of various exchange rates on the movement of NSE NIFTY index. Nevertheless, NSE NIFTY's influence on the exchange rates that are expressed in terms of Indian rupee was also estimated to identify causal effects. The lag order was set based on AIC criteria. The 13 years were split into three specific time durations (September 2005-September 2009, October 2009-October 2013 and November 2013-December 2018) to assess the short-term influence of movements in exchange rates on NSE NIFTY. Further to this, Granger causality test was also run for the overall period.

\subsubsection{Split Up Periods}

The split wise Granger causality test results show that the various currency pairs drive the nifty index in different periods. During the first split (2005-2009), the Euro and JPY were seen causing Nifty 50 movements. Nifty 50 was, in turn, Granger causing USD and CNY. In the Second split (2009-2013), Euro was seen as Granger causing Nifty and Nifty was found Granger causing Euro, JPY and GBP. These movements may be primarily contributed to the foreign trade figures. European Union, China and the USA were among the top 10 trading partners to India during those periods (Trade Statistics by Country I WITS n.d.).

The Final Split (2013-2018) further shows that USD, CNY and JPY are causing Nifty and Nifty causing USD and CNY. Along with the foreign trade figures (with China, USA, and Japan) the FII flows are also the reason for the bi-directional relationship between USD and Nifty. Overall, the research found that the short-term relationships between the various currency pairs and nifty index is primarily driven by the foreign trade figures and FII flows. Tables 4-6 show the granger causality test results for the split periods; September 2005 to September 2009, October 2009 to October 2013 and November 2013 to December 2018 respectively. 
Table 4. Granger causality in VAR Framework for the period September 2005-September 2009.

\begin{tabular}{|c|c|c|c|c|c|c|c|}
\hline $\begin{array}{l}\text { Independent } \\
\text { Variables }\end{array}$ & $\begin{array}{c}\text { Dependent } \\
\text { Variable }\end{array}$ & F Statistic & $p$-Value & $\begin{array}{c}\text { Independent } \\
\text { Variable }\end{array}$ & $\begin{array}{c}\text { Dependent } \\
\text { Variable }\end{array}$ & F Statistic & $p$-Value \\
\hline$\Delta \operatorname{lnUSD}$ & & 1.766 & 0.184 & & $\Delta \operatorname{lnUSD}$ & 8.457 & 0.003 \\
\hline$\Delta \operatorname{lnEUR}$ & & 3.060 & 0.015 & & $\Delta \operatorname{lnEUR}$ & 0.276 & 0.893 \\
\hline$\Delta \operatorname{lnCNY}$ & $\Delta \ln N S E$ & 1.546 & 0.214 & $\Delta \operatorname{lnNSE}$ & $\Delta \operatorname{lnCNY}$ & 7.248 & 0.007 \\
\hline$\Delta \operatorname{lnJPY}$ & & 12.50 & 0.000 & & $\Delta \ln J P Y$ & 0.223 & 0.636 \\
\hline$\Delta \ln G B P$ & & 0.008 & 0.926 & & $\Delta \ln G B P$ & 0.180 & 0.670 \\
\hline
\end{tabular}

Note: Granger Causality Null-No Granger Causality.

Table 5. Granger causality in VAR Framework for the period October 2009-October 2013.

\begin{tabular}{|c|c|c|c|c|c|c|c|}
\hline $\begin{array}{c}\text { Independent } \\
\text { Variables }\end{array}$ & $\begin{array}{c}\text { Dependent } \\
\text { Variable }\end{array}$ & F Statistic & $p$-Value & $\begin{array}{c}\text { Independent } \\
\text { Variable }\end{array}$ & $\begin{array}{c}\text { Dependent } \\
\text { Variable }\end{array}$ & F Statistic & $p$-Value \\
\hline$\Delta \operatorname{lnUSD}$ & & 1.225 & 0.293 & & $\Delta \operatorname{lnUSD}$ & 1.667 & 0.189 \\
\hline$\Delta \operatorname{lnEUR}$ & & 5.846 & 0.015 & & $\Delta \operatorname{lnEUR}$ & 8.446 & 0.003 \\
\hline$\Delta \operatorname{lnCNY}$ & $\Delta \operatorname{lnNSE}$ & 1.268 & 0.210 & $\Delta \operatorname{lnNSE}$ & $\Delta \operatorname{lnCNY}$ & 1.657 & 0.190 \\
\hline$\Delta \operatorname{lnJPY}$ & & 0.281 & 0.754 & & $\Delta \operatorname{lnJPY}$ & 4.433 & 0.011 \\
\hline$\Delta \operatorname{lnGBP}$ & & 0.594 & 0.552 & & $\Delta \ln G B P$ & 7.145 & 0.000 \\
\hline
\end{tabular}

Note: Granger Causality Null-No Granger Causality.

Table 6. Granger causality in VAR Framework for the period November 2013-December 2018.

\begin{tabular}{|c|c|c|c|c|c|c|c|}
\hline $\begin{array}{l}\text { Independent } \\
\text { Variables }\end{array}$ & $\begin{array}{c}\text { Dependent } \\
\text { Variable }\end{array}$ & F Statistic & $p$-Value & $\begin{array}{c}\text { Independent } \\
\text { Variable }\end{array}$ & $\begin{array}{c}\text { Dependent } \\
\text { Variable }\end{array}$ & F Statistic & $p$-Value \\
\hline$\Delta \operatorname{lnUSD}$ & & 4.636 & 0.000 & & $\Delta \operatorname{lnUSD}$ & 3.706 & 0.002 \\
\hline$\Delta \operatorname{lnEUR}$ & & 3.336 & 0.067 & & $\Delta \operatorname{lnEUR}$ & 0.000 & 0.982 \\
\hline$\Delta \operatorname{lnCNY}$ & $\Delta \ln N S E$ & 2.507 & 0.007 & $\Delta \operatorname{lnNSE}$ & $\Delta \operatorname{lnCNY}$ & 2.225 & 0.018 \\
\hline$\Delta \ln J P Y$ & & 5.464 & 0.019 & & $\Delta \operatorname{lnJPY}$ & 0.277 & 0.598 \\
\hline$\Delta \operatorname{lnGBP}$ & & 0.932 & 0.334 & & $\Delta \operatorname{lnGBP}$ & 0.2565 & 0.612 \\
\hline
\end{tabular}

Note: Granger Causality Null-No Granger Causality.

\subsubsection{Overall Period (2005-2018)}

The results of the Granger causality test (from 2005 to 2018) show that the changes in the USD, CNY, and JPY Granger cause NSE NIFTY implying that fluctuations in the exchange rate of USD, CNY, or JPY will cause volatility in NSE in the short-run. However, other exchange rates did not seem to have a causal relationship with the NSE NIFTY index. The USD/INR exchange rates and nifty movements are interconnected, which re-establishes the fact that Indian markets are still tracking the US economy and substantial dollar-denominated funding happens in the Nifty index. The dollar-denominated transactions further point out that the fund flows which gained momentum after quantitative easing (after 2009) have not stopped yet. This may mean that the Indian stock markets are still giving better spread in comparison to US domestic investments. This is evident from the latest charts of the United States and Indian 10 year Government securities. As of the 24 August 2020, Indian 10 year was trading at 6.22 levels and the US 10 year was at 0.64 levels (Trading Economics n.d.).

Another reason for the causal relationship between the above-mentioned exchange rates and the NIFTY index is the trade relations of India with these countries. The US became India's largest trade partner with a trading volume of $\$ 87.95$ billion in 2018-2019 by surpassing China with which the bilateral trade was worth $\$ 87.07$ billion (The Economic Times 2019). The causality between the trade-weighted dollar index ( $\Delta \ln$ Trade Weighted Dollar Index) and the NSE NIFTY ( $\Delta \ln N S E)$ was further examined to confirm the impact of an improved trade relationship between India and the US on NSE NIFTY. The VAR Granger test results with an F value of 4.056 is significant at 0.012 percent significance 
level and further strengthens the causal relationship. However, the reverse relationship between the variables did not seem to be significant, with an F value of 2.3056 and p-value of 0.129 . Table 7 shows the results of the Granger causality test for the period January 2005 to December 2018.

Table 7. Granger causality in VAR Framework for the period January 2005-December 2018.

\begin{tabular}{|c|c|c|c|c|c|c|c|}
\hline $\begin{array}{c}\text { Independent } \\
\text { Variables }\end{array}$ & $\begin{array}{c}\text { Dependent } \\
\text { Variable }\end{array}$ & F Statistic & $p$-Value & $\begin{array}{c}\text { Independent } \\
\text { Variable }\end{array}$ & $\begin{array}{c}\text { Dependent } \\
\text { Variable }\end{array}$ & F Statistic & $p$-Value \\
\hline$\Delta \operatorname{lnUSD}$ & & 6.990 & 0.000 & & $\Delta \operatorname{lnUSD}$ & 3.152 & 0.007 \\
\hline$\Delta \operatorname{lnEUR}$ & & 1.0244 & 0.311 & & $\Delta \operatorname{lnEUR}$ & 2.044 & 0.152 \\
\hline$\Delta \operatorname{lnCNY}$ & $\Delta \ln N S E$ & 6.242 & 0.000 & $\Delta \ln N S E$ & $\Delta \operatorname{lnCNY}$ & 1.7041 & 0.139 \\
\hline$\Delta \operatorname{lnJPY}$ & & 10.847 & $1.982 \times 10^{-5}$ & & $\Delta \operatorname{lnJPY}$ & 1.3125 & 0.269 \\
\hline$\Delta \operatorname{lnGBP}$ & & 0.0057 & 0.939 & & $\Delta \operatorname{lnGBP}$ & 0.6725 & 0.644 \\
\hline
\end{tabular}

Note: Granger Causality Null—No Granger Causality.

For the same period, the trade with Japan totaled $\$ 17.63$ billion (Embassy of India Japan 2020). The recent currency swap worth $\$ 75$ billion between India and Japan might have had a short-term impact on the capital markets in the country, especially on the National Stock Exchange (Oberoi 2018). Moreover, Japanese Yen being a safe haven, will appreciate at times of financial turbulence, hence, it can be said that Yen impacted the movements of the Nifty 50 index, i.e., when Yen appreciates it is possible that there is a pessimism in the global markets (Hampson n.d.) and this would eventually pass on to the Indian index. The analysis also points out that the INR market has started tracking the Chinese Yuan. In fact, Indian Rupee is more correlated with the Chinese Yuan than the USD. The reason being the rapidly expanding money supply pressurizing the Chinese regulators to devalue their currency, which makes the exports competitive for China. This would adversely impact the Indian trade, which gets reflected in the Nifty 50 index (Patel n.d.). Based on the results, Hypotheses 2, 4, and 5 are accepted.

It is also interesting to observe that the causal relationship between EUR, GBP, and NSE NIFTY index is not significant because the FII equity inflows in terms of GBP and Euro are not as massive as USD and JPY. The fund flows in terms of these currency denominations suggest that they are insufficient to cause any significant change in the Nifty 50 index (NSDL n.d.).

The Bidirectional causality results further revealed that the Nifty 50 index does influence the USD/INR exchange rates. There are multiple reasons for this. The prominent one being the Foreign Institutional Investors (FII). When the FIIs pour in money to the Indian stock markets, the money, in terms of USD, needs to be converted to INR, creating a demand for INR and its appreciation against USD (Khatri n.d.). From the financial year 2011-2012, the United States of America has the most FII investments in equity flows to the Indian markets. The USA's FPI inflow towards the Indian Equity markets for 2017-2018 was Rs.9,65,768 crores (NSDL n.d.). These flows substantiate that a part of USD/INR exchange rate fluctuations is due to dollar-denominated equity flows into the Indian Market. A stronger Nifty 50 would mean that the rupee stays strong against dollars because of the dollar infusion into the Indian equity market.

\subsection{Impulse Response Functions}

Impulse Response functions are used to figure out to what extent a shock in one of the exchange rates under study would affect the NSE NIFTY index over a period of 12 months for the entire study period. The results are given in Figure 3. 


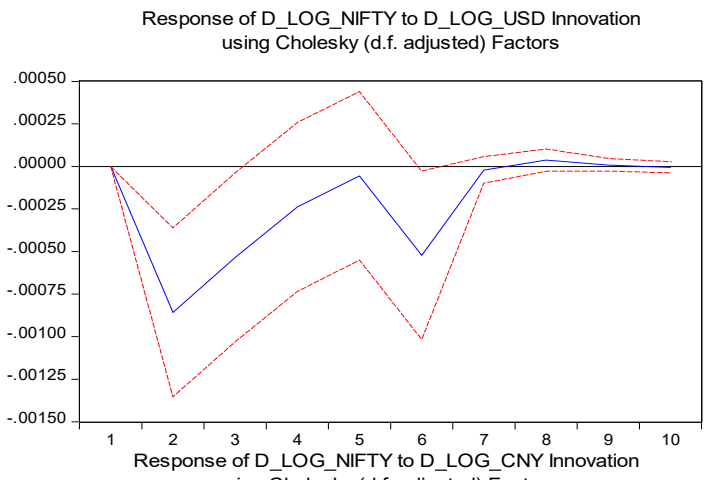
using Cholesky (d.f. adjusted) Factors

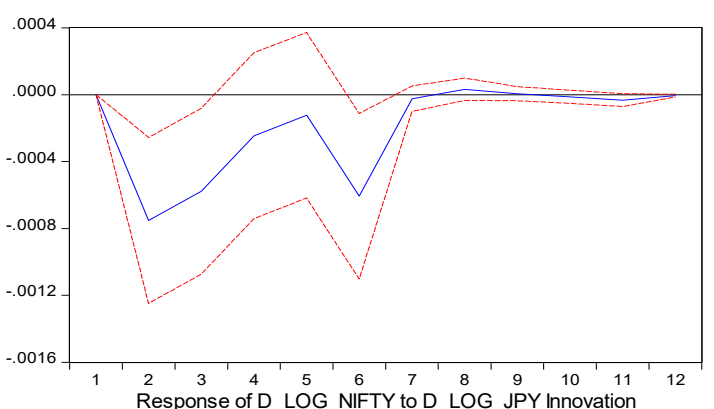
using Cholesky (d.f. adjusted) Factors
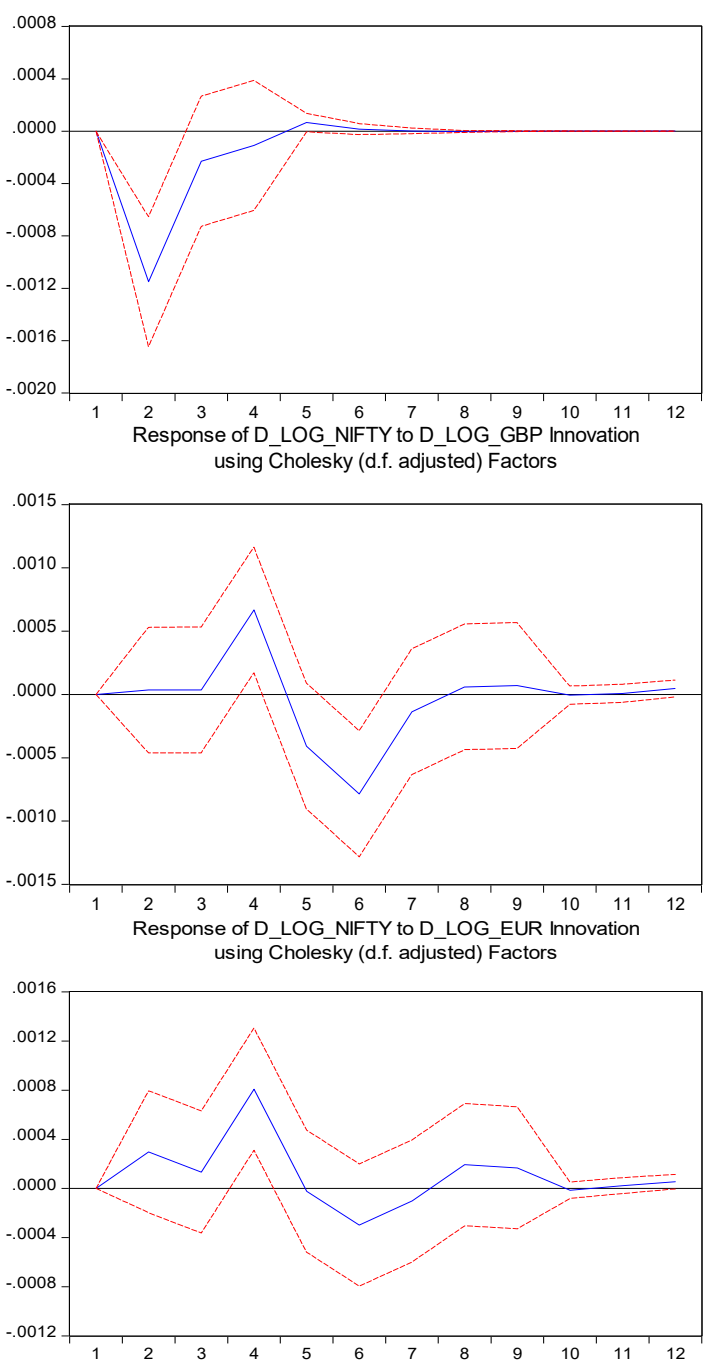

Figure 3. Impulse Response Analysis Results. 
The response of D_LOG_NIFTY to a shock caused by D_LOG_USD shows that NIFTY falls in the first and second period and then rises and converge to zero close to the 10th period. In the case of Chinese Yuan, a shock caused by D_LOG_CNY will result in the drop of D_LOG_NIFTY in the first two periods and then rises and converge to zero close to 10th period. D_LOG_NIFTY responds to the shock caused by D_LOG_JPY in a similar way as it responded to D_LOG_USD and D_LOG_CNY, where NIFTY drops starkly in the first two periods and then rises. Unlike the other two currencies, NIFTY totally converges to zero after the seventh period. The shock caused by D_LOG_GBP and D_LOG_EUR on D_LOG_NIFTY shows a different trend from the first three cases. D_LOG_NIFTY rises from second period and then falls starkly until sixth period. The shock caused by D_LOG_EUR also follows a similar pattern. However, both D_LOG_GBP and D_LOG_EUR do not converge to zero like the other three currencies.

\section{Conclusions}

This study aimed at analyzing the short-run and long-run linkages between exchange rates and NSE NIFTY index through a Johansen cointegration and a Granger causality test. The results of the cointegration analysis show that no long-run relationship exists between exchange rates and NIFTY index. This result implies that the variations in the exchange rates under this study may not have a significant influence on NIFTY index in the long-run, hence, the investors who are into long-term trading do not necessarily have to be cautious about the short-term fluctuations in the exchange rates. The Granger causality test results indicate that the USD, CNY, JPY exchange rates have a positive and significant relationship with NIFTY index. The findings are further supported by the Impulse Response Function analysis that gives the time required for convergence of NIFTY index following an initial shock. This finding indicates that the stakeholders need to keenly follow the short-run fluctuations in the above-mentioned exchange rates if their intention is to engage in shortterm trading. One of the limitations of this study is that it uses conventional methods of cointegration and Granger causality to assess the relationship between the variables. Future studies in this area should consider the volatility spillover effects using more appropriate methods.

Author Contributions: V.V.-Conceived the model-Methodology, Analysis, Results \& Discussions; D.K.K.-Results \& Discussions; M.B.-Analysis; F.N.—Literature Review. All authors have read and agreed to the published version of the manuscript.

Funding: This research received no external funding.

Institutional Review Board Statement: Not Applicable.

Informed Consent Statement: Not Applicable.

Data Availability Statement: Data available in a publicly accessible repository.

Conflicts of Interest: The authors declare no conflict of interest.

\section{References}

Adebiyi, Michael Adebayo, Adeniyi Olatunde Adenuga, Magnus Okoi Abeng, and Phebian N. Omanukwue. 2009. Oil price shocks, exchange rate and stock market behaviour: Empirical evidence from Nigeria. Paper presented at 14th Annual Conference of the African Econometric Society, Abuja, Nigeria, June 15.

Alile, Hayford I. 1984. The Nigerian Stock Exchange: Historical Perspective, Operations and Contributions to Economic Development. Central Bank of Nigeria Bullion, Silver Jubilee Edition 2: 65-69.

Alloza, Mario. 2017. A Very Short Note on Computing Impulse Response Functions. London: University College. Available online: http:/ / www.ucl.ac.uk/ \{\}uctp041/Teaching_files/Tutorial_IRF.pdf (accessed on 25 September 2020).

Bartov, Eli, and Gordon M. Bodnar. 1994. Firm valuation, earnings expectations, and the exchange-rate exposure effect. The Journal of Finance 49: 1755-85. [CrossRef]

Bhattacharya, Basabi, and Jaydeep Mukherjee. 2002. The nature of the causal relationship between stock market and macroeconomic aggregates in India: An empirical analysis. Paper presented at 4th Annual Conference on Money and Finance, Mumbai, India, March 1-3; pp. 401-26. 
Bhuvaneshwari, Dheyvendhren, and Krishnaraj Ramya. 2017. Cointegration and causality between stock prices and exchange rate: Empirical evidence from India. SDMIMD Journal of Management 8: 39-45. [CrossRef] [PubMed]

Chkili, Walid, and Duc Khuong Nguyen. 2014. Exchange rate movements and stock market returns in a regime-switching environment: Evidence for BRICS countries. Research in International Business and Finance 31: 46-56. [CrossRef]

Dornbusch, Rudiger, and Stanley Fischer. 1980. Exchange rates and the current account. The American Economic Review 70: 960-71.

Embassy of India Japan. 2020. India_Japan Economic Relations. Available online: https:/ /www.indembassy-tokyo.gov.in/india_ japan_economic_relations.html (accessed on 2 June 2020).

Engle, Robert F., and Clive W. J. Granger. 1987. Co-integration and error correction: Representation, estimation, and testing. Econometrica: Journal of the Econometric Society 55: 251-76. [CrossRef]

Franck, Peter, and Allan Young. 1972. Stock price reaction of multinational firms to exchange realignments. Financial Management 1: 66-73. [CrossRef]

Granger, Clive W. J. 1969. Investigating causal relations by econometric models and cross-spectral methods. Econometrica: Journal of the Econometric Society 37: 424-38. [CrossRef]

Griffin, John M., and René M. Stulz. 2001. International competition and exchange rate shocks: A cross-country industry analysis of stock returns. The review of Financial Studies 14: 215-41. [CrossRef]

Gulati, Deepti, and Monika Kakhani. 2012. Relationship between stock market and foreign exchange market in India: An empirical study. Pacific Business Review International 5: 66-71.

Gurgul, Henryk, and Łukasz Lach. 2012. The Association between Stock Market and Exchange Rates for Advanced and Emerging Markets-A Case Study of the Swiss and Polish Economies. Munich: University Library of Munich.

Hampson, Rebecca. n.d. Is the Yen Still a Safe Haven? Available online: https://www.etfstream.com/features/is-the-yen-still-a-safehaven/ (accessed on 24 August 2020).

He, Jia, and Lilian K. Ng. 1998. The foreign exchange exposure of Japanese multinational corporations. The Journal of Finance 53: 733-53. [CrossRef]

Ibrahim, Mansor H. 2000. Cointegration and Granger causality tests of stock price and exchange rate interactions in Malaysia. ASEAN Economic Bulletin 17: 36-47. [CrossRef]

Ihsan, Anjum, Qadar Bakhsh Baloch, and Shahid Jan Kakakhel. 2015. Relationship between Exchange Rates and Stock Market Index: Evidence from the Pakistani Stock Market. Abasyn University Journal of Social Sciences 8: 17-36.

Johansen, Søren. 1988. Statistical analysis of cointegration vectors. Journal of Economic Dynamics and Control 12: 231-54. [CrossRef]

Jorion, Philippe. 1990. The exchange-rate exposure of US multinationals. Journal of Business 63: 331-45. [CrossRef]

Khatri, Yogita. n.d. Indian Rupee: How Closely Are the Rupee and Stock Market Movements Correlated? Available online: https:/ / economictimes.indiatimes.com/wealth/invest/how-closely-are-the-rupee-and-stock-market-movements-correlated/ articleshow /59189946.cms?from=mdr (accessed on 8 December 2020).

Kumarasamy, Umanath, and P. Chellasamy. 2017. An Empirical Study on Indian Stock Market and Foreign Exchange Rates-A Review on Relationship. International Journal of Management and Development Studies 6: 1-9.

Lee, Jung Wan, and Tianyuan Frederic Zhao. 2014. Dynamic relationship between stock prices and exchange rates: Evidence from Chinese stock markets. Journal of Asian Finance, Economics and Business 1: 5-14. [CrossRef]

Mishra, Alok Kumar. 2004. Stock market and foreign exchange market in India: Are they related? South Asia Economic Journal 5: $209-32$. [CrossRef]

Mroua, Mourad, and Lotfi Trabelsi. 2020. Causality and Dynamic Relationships between Exchange Rate and Stock Market Indices in BRICS Countries. Journal of Economics, Finance and Administrative Science. [CrossRef]

Nath, Golaka C., and G. P. Samanta. 2003. Relationship between Exchange Rate and Stock Prices in India-An Empirical Analysis. Available online: https:/ / papers.ssrn.com/sol3/papers.cfm?abstract_id=475823 (accessed on 2 June 2020).

NSDL. n.d. Available online: https:/ / www.fpi.nsdl.co.in/web/Reports/ReportDetail.aspx?RepID=81 (accessed on 8 December 2020).

Oberoi. 2018. What's in It for India in $\$ 75$ Billion Currency Swap Pact with Japan. Available online: https://economictimes.indiatimes. $\mathrm{com} /$ markets/forex/whats-in-it-for-india-in-75-billion-currency-swap-pact-in-japan/articleshow / 66443182.cms (accessed on 28 May 2020).

Olugbenga, Adaramola Anthony. 2012. Exchange rate volatility and stock market behaviour: The Nigerian Experience. European Journal of Business and Management 4: 31-39.

Patel, Bhavik. n.d. Rupee: View: Rupee Is Following in the Footsteps of Yuan-The Economic Times. Available online: https:/ / economictimes.indiatimes.com/markets/forex/view-rupee-is-following-the-footsteps-of-yuan/articleshow / 711164 23.cms?from $=$ mdr (accessed on 25 August 2020).

Pesaran, H. Hashem, and Yongcheol Shin. 1998. Generalized impulse response analysis in linear multivariate models. Economics Letters 58: 17-29. [CrossRef]

Phylaktis, Kate, and Fabiola Ravazzolo. 2005. Stock prices and exchange rate dynamics. Journal of International Money and Finance 24: 1031-53. [CrossRef]

Poornima, S., and M. Ganeshwari. 2016. Relationship between exchange rates and stock market index: Evidence from the Indian stock market. International Journal of Science and Research (IJSR) 5: 16-18. 
The Economic Times. 2019. Rupee: View: Rupee Is Following in the Footsteps of Yuan. Available online: https://economictimes. indiatimes.com/markets / forex/view-rupee-is-following-the-footsteps-of-yuan/articleshow $/ 71116423 . \mathrm{cms}$ ?from=mdr (accessed on 25 August 2020).

Sims, Christopher A. 1980. Macroeconomics and reality. Econometrica: Journal of the Econometric Society 48: 1-48. [CrossRef]

Trade Statistics by Country I WITS. n.d. Available online: https:/ / wits.worldbank.org/countrystats.aspx (accessed on 24 December 2020).

Trading Economics. n.d. India Government Bond 10Y I 1994-2020 Data | 2021-2022 Forecast I Quote I Chart. Available online: https: // tradingeconomics.com/india/government-bond-yield (accessed on 24 August 2020).

Zubair, Abdulrasheed. 2013. Causal relationship between stock market index and exchange rate: Evidence from Nigeria. CBN Journal of Applied Statistics 4: 87-110. 